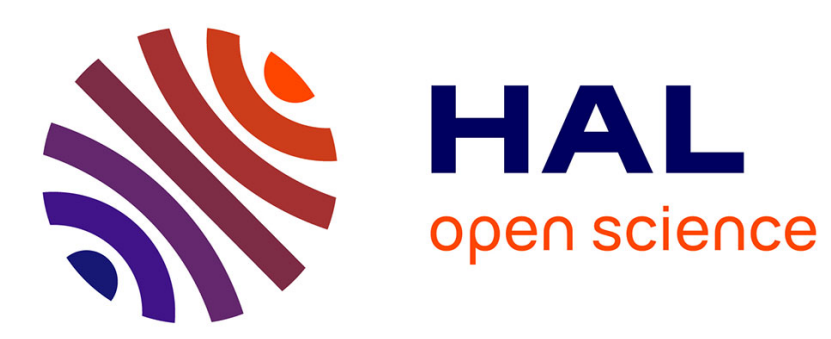

\title{
Valorization of Aggregated Decentral Flexibilities
}

Andreas Dietrich, Christoph Weber

\section{To cite this version:}

Andreas Dietrich, Christoph Weber. Valorization of Aggregated Decentral Flexibilities. 3rd and 4th International Conference on Smart Energy Research (SmartER Europe 2016 and 2017), Feb 2017, Essen, Germany. pp.178-187, 10.1007/978-3-319-66553-5_13 . hal-01691201

\section{HAL Id: hal-01691201 \\ https://hal.inria.fr/hal-01691201}

Submitted on 23 Jan 2018

HAL is a multi-disciplinary open access archive for the deposit and dissemination of scientific research documents, whether they are published or not. The documents may come from teaching and research institutions in France or abroad, or from public or private research centers.
L'archive ouverte pluridisciplinaire HAL, est destinée au dépôt et à la diffusion de documents scientifiques de niveau recherche, publiés ou non, émanant des établissements d'enseignement et de recherche français ou étrangers, des laboratoires publics ou privés.

\section{(c)(1)}

Distributed under a Creative Commons Attribution| 4.0 International License 


\title{
Valorization of aggregated decentral flexibilities \\ Opportunities and challenges under current German regulatory framework and market conditions
}

\author{
Andreas Dietrich, Christoph Weber \\ University of Duisburg Essen \\ Andreas.Dietrich@uni-due.de, Christoph.Weber@uni-due.de
}

\begin{abstract}
In power systems with high shares of fluctuating renewable electricity production, flexibility options play an important role for system stability. Supplementary to existing technologies, new approaches for the provision of flexibility are under discussion. Among these, emphasis is put on decentral flexibilities at residential and commercial level that may become available by aggregation and market oriented coordination. Because future contributions of this concept to the coverage of flexibility demand will not only depend on technical solutions but also on viable business models, questions of economic incentives as well as regulatory issues are of particular relevance. Based on preliminary findings of an ongoing research project, this paper categorizes decentral flexibilities and presents key determinants for their utilization and merit. Considering current German regulatory framework and market conditions, major challenges along the aggregators' value chain are discussed. It turns out that under today's conditions the aggregation of (small) decentral flexibilities is a demanding business. On the one hand, it is difficult to reach an overall competitive cost level. On the other, misplaced incentives at the end customer level hamper the procurement of flexibilities from an aggregator's perspective. Furthermore, revenue potentials on the sales side are limited due to a wholesale market situation that is characterized by overcapacities.
\end{abstract}

Keywords: decentral flexibility, virtual power plant, business model, aggregator, regulation, smart grid, power to heat, thermal storage, electrical storage

adfa, p. 1, 2011.

(C) Springer-Verlag Berlin Heidelberg 2011 


\section{$1 \quad$ Introduction}

The transformation of the German electricity system towards renewable sources causes an increasing demand for flexibility to ensure a balance between fluctuating loads and intermittent wind and solar power production. Besides conventional technologies like pump storages and gas turbines as well as measures of network expansion, it is expected that other flexibility options play an essential role in the future. These include heat pumps, storage heaters, small combined heat and power (CHP) units and residential photovoltaic (PV) battery storages. Nowadays, operating modes of these installations are determined by individual heat or load demand profiles in most cases. Therefore, existing flexibility potentials remain unused from a systems' perspective.

Concepts for a system-oriented utilization of decentral flexibilities have gained significance in research over the last years. Referred to as "virtual power plants" or "virtual storages", some first approaches for aggregation and market oriented operation of distributed flexibility potentials have been implemented in practice already (inter alia Fenecon (2015); GASAG (2016); N-ERGIE (2015)). However, for a widespread dissemination of these concepts, sustainable business models that can maintain their position in competition with conventional flexibility options are an essential precondition. In this context, besides technical tasks, questions of economic incentives as well as regulatory issues are of particular relevance. This paper provides an overview about opportunities and challenges for the valorization of aggregated decentral flexibilities with a special focus on the current German regulatory framework and market conditions. The remainder is structured as followed: Section 2 defines three categories of decentral flexibilities and identifies key determinants for their utilization and merit. Section 3 takes a closer look into selected problem areas along the value chain of procurement, management and sales of aggregated flexibilities. Section 4 concludes and gives an outlook.

\section{Categorization of decentral flexibilities and determinants for their utilization and merit}

For leveraging decentral flexibilities, the concept of aggregators is believed to be essential in order to lower transaction costs and overcome market entry barriers (e.g. in the reserve power market). An aggregator is expected to become contracting party for customers who are in possession of decentral flexibility potentials and to market these flexibilities on the relevant markets. Such market players may be conventional actors within the balancing group scheme (suppliers and buyers of electricity) or they may enter the market as independent service providers. For the latter, an integration of the new market role "aggregator" into the regulatory framework is part of the current discussion at European and national level (European Commission (2016), p. 19 ff.; BMWi (2015), p. 72; BMWi (2016), p. 168). 
Flexibility potentials can emerge from a large variety of technical systems and different kinds of customers, whereby utilization and merit of each flexibility depend on generic as well as on specific factors. From the perspective of an aggregator, figure 1 depicts the key generic determinants.

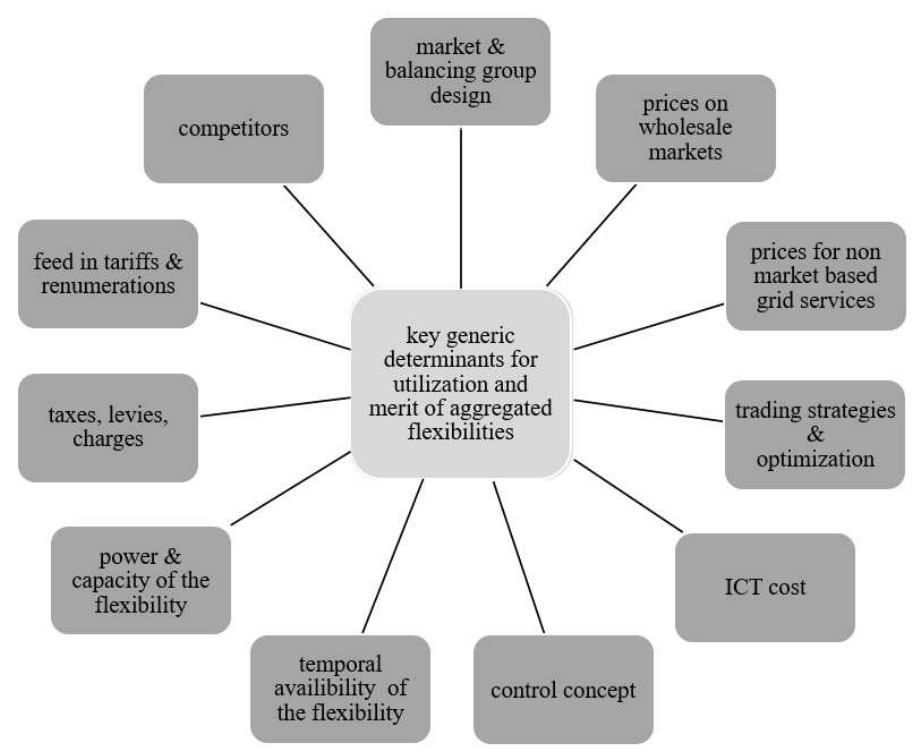

Fig. 1. Key generic determinants for utilization and merit of aggregated flexibilities

For an appropriate analysis of the specific factors, a distinction hast to be made between customers in the role of consumers, prosumers or producers.

\subsection{Consumers}

The legal definition of an end consumer is as a natural or legal person who consumes electricity (EEG (2014), § $3 \mathrm{Nr} .33$ ) or who buys electricity for its own use (EnWG (2005), § $3 \mathrm{Nr}$. 25), which may include prosumers as well as producers. In this paper, we only consider customers without power generation capabilities as a consumer; flexibility potentials then arise exclusively from modifications in the consumers' load profile. Various power-consuming devices may be considered and the analysis of demand side management has been part of various recent research activities (B.A.U.M. (2014); FfE (2016); VDE (2012). The largest existing flexibilities are however in electric heating systems, combined with thermal storage capacities (dena (2010), p. 410 ff.). Since separate measurement as well as billing exist for most of these systems, the specific potentials for these flexibilities may be determined. Furthermore, customer and aggregator may conclude separate contracts in addition to existing contracts for general power supply. 


\subsection{Prosumers}

In the energy sector, there is no universally agreed definition for the term "prosumer" until now. For example, according to IEA-RETD (2014, p. 13), a prosumer is a consumer who produces his own power from a range of various onsite generators. In European Commission (2015, p. 2), prosumers are defined as businesses and households who "produce and consume some or all of their electricity, either instantaneously or in a deferred manner through decentralized storage, behind the connection point with the grid". Based on the legal definition for self-usage (EEG (2014); § 3 Nr. 19), this can be specified in greater detail for the German context: Firstly, generation and consumption have to be in spatial proximity, ensuring that self-consumed electricity does not transits through public grid infrastructure. Secondly, the prosumer must act as an operator of the generation unit. This makes not ownership mandatory for the unit but economic disposal and the possibility to influence the operation mode (BNetzA (2016), p. 22). Thus, the aggregators' potential customer base in the category of prosumers also includes customers with power generating units in leasing or contracting agreements ${ }^{1}$.

\subsection{Producers}

This category includes customers, who operate power-producing systems and do not fulfill the above-mentioned conditions of a prosumer. Therefore, apart from electricity used for internal consumption in order to maintain operational state, the total quantity of produced electricity is fed into public grid. This applies for detached power plants like large-scale PV and wind farms as well as for CHP units that supply local heat networks.

\section{Major challenges along the value chain}

The value proposition of aggregators is based on a three-part value chain: procurement, management and sales of flexibility (see Fig. 2). In each of these areas, specific challenges for the business model of aggregation and the valorization of decentral flexibilities arise. These are discussed subsequently.

1 Recently, new business models in the field of ,tenant electricity“ were implemented. According to our classification, these customers are consumers (tenants) or producers (plant operator/owner). However, these business models limit a market-oriented utilization of flexibility potentials due to incentive mechanisms that are comparable to prosumers. 


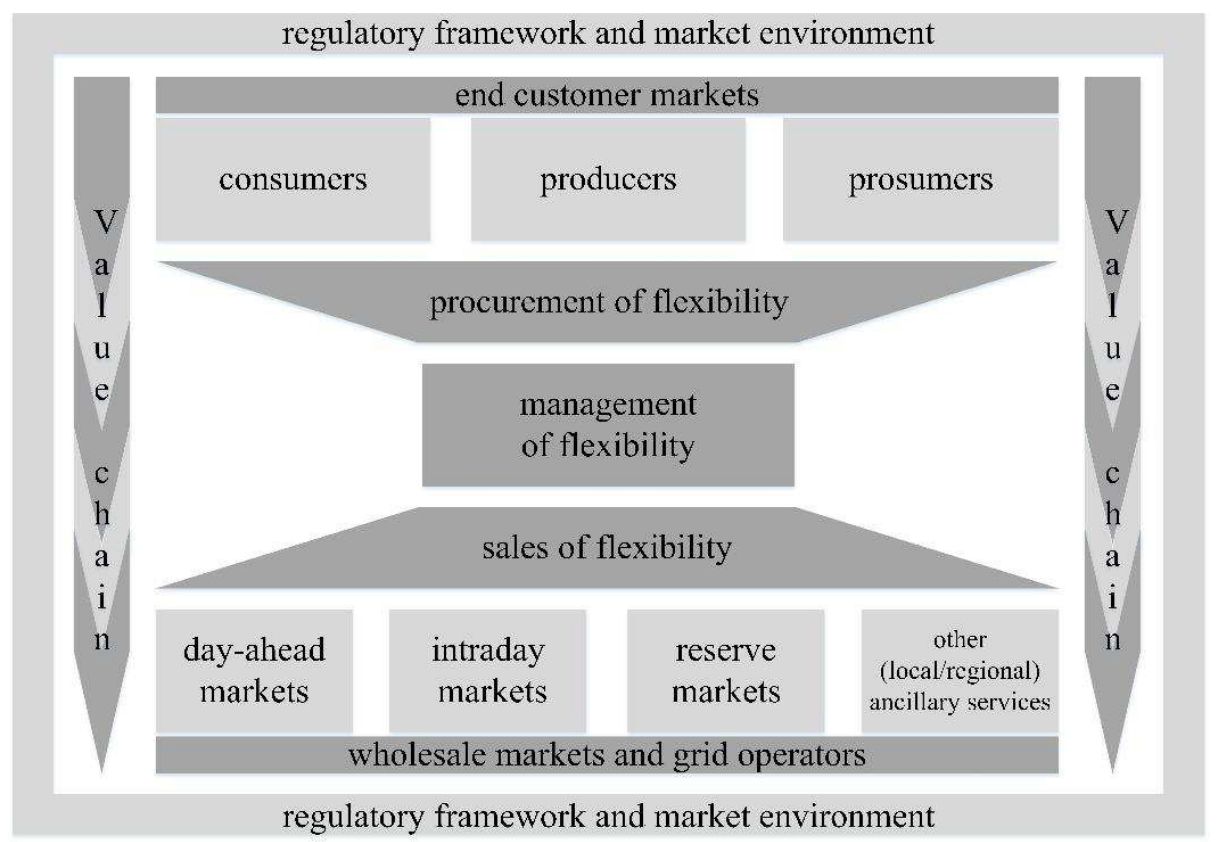

Fig. 2. Aggregators value chain

\subsection{Procurement}

On the procurement side, financial benefits for customers play a major role to incentivize participation in the aggregator concept. Firstly, given that several aggregators may enter the market in the future, the creation of competitive "flexibility-contracts" is a fundamental challenge. This implies an efficient utilization of flexibility over the whole value chain, especially with regard to a cost-effective system for control and management tasks. Furthermore, the overall trading strategy for valorization has to be profitable. Secondly, contracts have to improve the status quo in cost for consumers. For producers and prosumers, the provision of flexibility has to enhance the profitability of their power-generating units.

Experience gained inter alia in the project "Die Stadt als Speicher" shows that development, implementation and operation of a reliable ICT infrastructure requires considerable efforts. Depending on the control concept, prices or control signals must be transmitted and processed. Especially small and older installations are however neither equipped with external interfaces nor with internal devices for an intelligent signal processing. In these cases, the procurement and utilization of flexibility fails due to technical reasons or is associated with high cost due to an individual retrofit. Even for newer installations, it turns out that the establishment of unit connectivity can be demanding. As long as costs for ICT, at least partly, are not part of business-as-usual costs, they have to be financed through the flexibility marketing, diminishing consequently the 
financial benefits for customers and aggregators. Even if standardized and scalable solutions become available at low cost, aggregators will (have to) focus on procuring flexibilities, whose expected market values are in an appropriate relationship to expenses for acquisition and technical integration. These values are strongly depending on the customer's specific degree of flexibility as well as on the overall amount of produced or consumed electricity. Here, a disadvantage arises for small systems in the household segment from the outset. Large systems can also become less attractive if they are subject to low temporal availability. This problem is of particular relevance for heat-related systems in the following two cases: 1) if thermal storage capacities are insufficient and heat demand has to be covered or 2) if long-lasting periods without heat demand occur.

Besides these general aspects, the procurement of decentral flexibility is strongly affected by incentive mechanisms and regulatory issues that are specific for each customer category.

\subsubsection{Procurement of flexibilities with consumers}

For most consumers, existing supply tariffs for electric heating systems are lower than standard supply rates. This is mainly due to lower grid charges and concession fees. Local network operators usually define specific grid charges for installations which do not consume during peaking hours or which may be disconnected eventually by the network operators. The legal basis for such tariffs is given through $\S 19$ of the Stromnetzentgeltverordnung (StromNEV (2005)). So far, network operators mostly define specific grid charges for electric storage heating being part in the ripple control system. Here, non-peak time periods and enabling times are so far determined year-onyear and fixed for the quarter. Hence, installations in an operation mode based on shortterm market signals may usually not benefit from the same reduced network tariffs. Thus, it is challenging for aggregators to offer tariffs that improve consumers' status quo; the difference in network charges has to be over-compensated by cost advantages from short-term procurement of electricity.

Higher concession fees applied by the municipalities may further amplify this effect. The level of the concession fee is dependent on the type of tariff applied to the customer ${ }^{2}$. Specifically, a lower level is mandatory for customers benefitting of a so-called "Schwachlasttarif". This has been traditionally the tariff applicable to electric storage heating systems included in the ripple control. Yet it is unclear whether and under what conditions an innovative pricing structure proposed by an aggregator could qualify as "Schwachlasttarif".

2 Legally, this is valid primary facie for the maximum level of the concession fee according to the Konzessionsabgabeverordnung ( $\$ 2 \mathrm{KAV}(1992)$ ). Yet, municipalities mostly stick in practice close to the upper bound of the allowed fee level. 
Besides this, relative savings for consumers are generally lower than relative procurement savings on wholesale markets for two reasons: Firstly, additional price components such as taxes, levies and charges are paid on a per unit base. Secondly, tariffs have to include aggregators' profit margins and risk mark ups. As long as significant benefits for consumers are hard to realize, incentives for a market-oriented provision of load flexibility are low.

\subsubsection{Procurement of flexibilities with prosumers}

In the case of prosumers, the aggregators' options for a successful procurement are also limited under the current regulatory framework. Economic incentives for self-consumption of self-produced electricity arise, if its value exceeds the benefits of an alternative use. Even though self-consumption of self-produced electricity is subject to the value added tax and parts of the renewable levy ("EEG-Umlage") in many cases, high electricity rates for general supply lead to a situation where self-consumption is a key prerequisite for profitability and the first best solution from a prosumer's perspective. Consequently, flexibility potentials are used for an electricity-driven operation mode of CHP units and PV owners take measures for an enhancement of self-consumption rates. As long as excess production is refunded by conventional feed in tariffs and market prices cannot compete against them, these amounts will not be put at the disposal of an aggregator either. Additional obstacles arise from the prohibition of multiple sale ("Doppelvermarktungsverbot") that interdicts a complementary provision of reserve power within the scheme of fixed EEG tariffs.

Furthermore, financial benefits from self-consumption are bound to the prosumers' legal status as an operator ("Betreiber"). Legal terms and juridical interpretations emphasize that this requires prosumers to take responsibility of the unit operation mode as well as of the related economic risks. Until now, the interpretation of these terms is not standardized and therefore subject of legal case-by-case assessments (BGH (2008); BNetzA (2016), p. 22). If the concept of aggregation jeopardizes the prosumers' status as operators, financial incentives for provision of flexibility are low in a prosumers' perspective. Here, a more transparent legislation that creates legal certainty for market actors is needed.

\subsubsection{Procurement of flexibilities with producers}

Yet even in the absence of opportunities for self-consumption, a market oriented provision of flexibility may not substantially improve the status quo in profits for most owners of CHP or PV systems: Notably, a separate compensation for flexibility is not foreseen under the traditional feed-in tariff for renewable installations. The feed-intariff supports a "produce and forget" approach for renewable generation. And the support mechanism for CHP units defined by the CHP law (KWKG (2015), § 4, Nr. 3) also includes provisions for such an approach: If the CHP operator and the network operator do not agree differently, the CHP operator will receive a bonus on top of a market- 
based but time-invariant electricity price. This so-called reference price is determined as an average of all hourly wholesale market prices of the previous quarter. Since it is independent of the current spot market price, no benefits are achieved when the power generation is adjusted to meet high market prices.

However, this changes if the CHP operator decides to go for so-called direct marketing, i.e. when he enters a contract with an electricity trader or an aggregator. Then the price may be dependent on the operation and the corresponding spot price. Such direct marketing is mandatory for all CHP units with a nameplate capacity exceeding $100 \mathrm{~kW}$ according to the latest version of the KWKG (KWKG (2015), § 4, Nr. 1). Similarly direct marketing has become mandatory for new renewable plants, in the EEG 2017 (EEG (2014), § 21) a similar limit of $100 \mathrm{~kW}$ is set as general rule.

For the procurement of decentral flexibilities, two consequences are notable: Firstly, the limit of $100 \mathrm{~kW}$ is obviously not relevant for households and small commercial sites, so the producers may stay in the conventional feed-in tariff respectively bonus system. Yet they may freely shift to the direct marketing alternative and will not be penalized for doing so. Secondly, an aggregator can offer them better revenues in counterpart to flexible operation. Yet the relative improvement for the producers will be usually limited, due to the high level of bonus respectively market premium, since these are paid on a per unit basis.

\subsubsection{Implications}

To summarize, the following aspects are key for the procurement of decentral flexibilities: Firstly, revenues from trading on wholesale markets cannot compete against existing feed-in tariffs. Secondly, end consumer electricity rates serve as a decisive driver of profitability in case of prosumers and create strong incentives for an operation mode that increases self-consumption. To overcome these obstacles, the regime of taxes, levies and surcharges on end consumer prices and on self-consumption needs to be profoundly modified. Furthermore, an extension of mandatory direct marketing to small production units would foster the development of aggregators' customer portfolio.

\subsection{Management}

On the management side, regulatory issues and institutional requirements have a major influence on utilization and merit of aggregated flexibilities. 


\subsubsection{Regulatory issues for management}

In the field of regulatory issues, several key restraints have recently been eased. For example, the abolishment of obligatory standard load profiles now enables an efficient valorization of small flexible consumers from a balancing group perspective. For aggregators who do not take the role of a supplier, the provision of reserve power by demand side management has been facilitated since progress has been made on the rules for opening of balancing groups (StromNZV (2005), §26a; bne (2016). Furthermore, prequalification procedures for reserve power have been adjusted, in particular with respect to pooling solutions for battery storage systems (Deutsche ÜNB (2016)). Regulatory reforms are still needed in the field of grid and concession fee regulation. Because grid operators' peak load times are determined year-on-year and fixed for the quarter, flexible operation can result in higher charges, diminishing incentives for the management of load flexibility. Major regulatory barriers for a flexibilisation of the German electricity system, as well as proposals for their removal, have been identified in BMWi (2015). In addition to the issues mentioned above, it can be expected that further improvements in the regulatory framework will have positive effects on the management of aggregated decentral flexibilities.

\subsubsection{Institutional requirements for management}

However, institutional requirements must be met as well for a successful management and the aggregator himself has to be vested with a broad range of competencies. A comprehensive single-handedly roll out of these business models will thus be very challenging for small companies. The following key competences have been identified: Firstly, flexibility has to be linked to the relevant wholesale markets. Besides a trading system, trading strategies must be implemented, wherefore professional trading expertise and knowledge in optimization is vital. Here, also forecasting capabilities for market prices and individual customers' loads are necessary. If valorization on intraday markets is intended, appropriate human resources for 24-hour trading are needed. Secondly, the operation of a reliable ICT infrastructure that serves as technical backbone for aggregation and management is crucial. Finally, competencies in acquisition and retention of profitable customers, as suppliers of flexibility, are essential. This also includes the arrangement of new contracts with innovative and competitive pricing policies as well as adjusted billing systems. In this context, abilities for an accurate valuation of potentials and risks of specific flexibilities have to be present. Many of these aspects are not among the core competencies of small companies like public utilities. Even if they become part of strategic partnerships or apply outsourcing, it is obvious that the business model "aggregator" is related to considerable investment and operating costs. This puts even more pressure on profitability if economies of scale can hardly be realized. This is particularly to be expected in small and heterogeneous flexibility pools. 


\subsection{Sales}

On the sales side, spot and reserve markets offer a variety of products that are suitable for short-term sales, even for medium sized aggregators. Products for flexibilities as well as market access conditions have advanced significantly over the last years. Since changes in national and European market designs aim inter alia at enhancing the provision of flexibility, one can expect that existing barriers on the sales side (e.g. in minute and secondary reserve product design) will be reduced further (BNetzA (2015)).

However, incentives for market participation arise mostly from expected revenues. Current spot market prices are low and exhibit quite small volatility. As such, they don't hold out the prospects of sufficient profits from power production or battery storage operation. Given the current market situation characterized by overcapacities, reserve markets are also affected by price erosion. Yet, economic benefits from wholesale trading of flexibility emerging from optimized purchasing for flexible power consumers have not been tapped so far.

\section{Conclusion}

The research shows, that the aggregation of small decentral flexibilities is a challenging business under today's conditions. In future, this concept could gain importance, if standardized and scalable ICT solutions lead to cost savings, especially in the field of unit connectivity. Furthermore, wholesale market prices have to indicate a demand for flexibility and a reduction of misplaced incentives on the end costumer side as well as in grid tariff schemes is required. Since this concept will be in competition with other flexibility options, it remains to be seen, whether aggregated small flexibilities can be brought to a competitive cost level.

\section{Acknowledgement}

This research has been funded by the Federal Ministry of Economics and Technology (BMWi) of Germany within the framework of the joint project "Die Stadt als Speicher" (project number 0325527C). 


\section{References}

B.A.U.M. (2014): E-Energy Abschlussbericht, Ergebnisse und Erkenntnisse aus der Evaluation der sechs Leuchtturmprojekte, http://www.digitale-technologien.de/DT/Redaktion/DE/Downloads/ab-gesamtbegleitforschung.pdf?__blob=publicationFile \&v=4

BGH (2008): Urteil vom 13. Februar 2008 - VIII ZR 280/05

https://www.clearingstelle-eeg.de/files/BGH_080213_VIII_ZR_280-05.pdf

bne (2016): Branchenleitfaden, Regelleistungserbringung durch Drittpartei-Aggregatoren,

http://www.bne-onli-ne.de/de/system/files/files/attachment/Branchenleitfaden\%20Drittpartei-Aggregator.pdf

BNetzA (2015): Festlegungsverfahren zur Weiterentwicklung der Ausschreibungsbedingungen und Veröffentlichungspflichten für Sekundärregelung und Minutenreserve, https://www.bundesnetzagentur.de/DE/Service-Funktionen/Beschlusskammern/1BKGeschaeftszeichen-Datenbank/BK6-GZ/2015/2015_0001bis0999/BK6-15-158/BK615-158_Eckpunktepapier_vom_23_11_2015.pdf?_blob=publicationFile \&v=2

BNetzA (2016): Leitfaden zur Eigenversorgung; https://www.bundesnetzagentur.de/SharedDocs/Downloads/DE/Sachgebiete/Energie/Unternehmen_Institutionen/ErneuerbareEnergien/Eige nversorgung/Finaler_Leitfaden.pdf?__blob=publicationFile \&v=2

BMWi (2015): Ein Strommarkt für die Energiewende, Ergebnispapier des Bundesministeriums für Wirtschaft und Energie (Weißbuch), http://www.bmwi.de/BMWi/Redaktion/PDF/Publikationen/weissbuch, property=pdf,bereich=bmwi2012, sprache=de,rwb $=$ true.pdf

BMWi (2016): Entwurf eines Gesetzes zur Weiterentwicklung des Strommarktes (Strommarktgesetz),

http://www.bmwi.de/BMWi/Redaktion/PDF/E/entwurf-eines-gesetzes-zurweiterentwicklung-des-strommarktes, property=pdf,bereich=bmwi2012, sprache $=$ de, $r w b=$ true.pdf

dena (2010): dena-Netzstudie II, https://www.dena.de/fileadmin/user_upload/Download/Dokumente/Studien Umfragen/Endbericht_dena-Netzstudie_II.PDF

Deutsche ÜNB (2016): Anforderungen an die Speicherkapazität bei Batterien für die Primärregeleistung, https://www.regelleistung.net/ext/download/anforderungBatterien 
EEG (2014): Erneuerbare-Energien-Gesetz vom 21. Juli 2014 (BGB1. I S. 1066), das durch Artikel 2 des Gesetzes vom 22. Dezember 2016 (BGB1. I S. 3106) geändert worden ist

EnWG (2005): Energiewirtschaftsgesetz vom 7. Juli 2005 (BGBl. I S. 1970, 3621), das zuletzt durch Artikel 3 des Gesetzes vom 22. Dezember 2016 (BGBl. I S. 3106) geändert worden ist

European Commission (2016): Proposal for a directive of the European parliament and of the council on common rules for the internal market in electricity (recast), http://ec.europa.eu/energy/sites/ener/files/documents/1_en_act_part1_v7_864.pdf

Fenecon (2015): FENECON vermarktet Flexibilität von dezentralen Stromspeichersystemen, press release Mai 19, 2015,

https://fenecon.de/web/binary/saveas?model=ir.attachment\&field=datas\&file-

name_field=name $\& \mathrm{id}=509 \& \mathrm{t}=1432038167671$

FfE (2016): Wissenschaftliche Projektbegleitung des Projektes DSM Bayern, https://www.ffegmbh.de/images/stories/Berichte/456_dsm-in-bayern/160809_Wissenschaftliche_Projektbegleitung_DSM-Bayern_final.pdf

GASAG (2016): GASAG-EcoPool seit einem Jahr erfolgreich, press release June 19, 2016;

https://www.gasag.de/unternehmen/presse/presseinformationen/20160719-pm-er-

folgsmeldung-ecopool-1jahr

IEA-RETD (2014): Residential Prosumers - Drivers and Policy Options (REProsumers),

http://iea-retd.org/wp-content/uploads/2014/06/RE-PROSUMERS_IEA-

RETD_2014.pdf

KAV (1992): Konzessionsabgabenverordnung vom 9. Januar 1992 (BGB1. I S. 12, 407), die zuletzt durch Artikel 3 Absatz 4 der Verordnung vom 1. November 2006 (BGB1. I S. 2477) geändert worden ist

KWKG (2015): Kraft-Wärme-Kopplungsgesetz vom 21. Dezember 2015 (BGB1. I S. 2498), das durch Artikel 1 des Gesetzes vom 22. Dezember 2016 (BGB1. I S. 3106) geändert worden ist

N-ERGIE (2015): N-ERGIE und Fraunhofer IISB kooperieren bei Regelleistung, press release October 2, 2015,

https://www.n-ergie.de/header/presse/mitteilungen/archiv/archiv-2015/n-ergie-undfraunhofer-iisb-kooperieren-bei-regelleistung.html 
StromNZV (2005): Stromnetzzugangsverordnung vom 25. Juli 2005 (BGB1. I S. 2243), die zuletzt durch Artikel 5 des Gesetzes vom 29. Au-gust 2016 (BGB1. I S. 2034) geändert worden ist

VDE (2012): Demand Side Integration, Lastverschiebungspotenziale in Deutschland; Verband der Elektrotechnik Elektronik Informationstechnik e. V. 